\title{
Synthesis, Characterization of Symmetrically Substituted Metal(II) Octa-1-(3-bromophenyl)methanimine Phthalocyanine
}

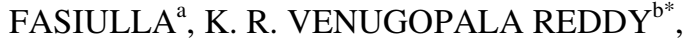 \\ J. KESHAVAYYA ${ }^{\mathrm{c}}$ and B. CHANDRESHEKHAR KUMAR ${ }^{\mathrm{a}}$
}

${ }^{\mathrm{a}}$ Department of Chemistry, Manipal Institute of Technology, Manipal, Udupi District -576104, Karnataka, India

${ }^{\mathrm{b}}$ Department of Studies in Industrial Chemistry, Sahyadri Science College, Shimoga -577201, Shimoga District, Karnataka, India

${ }^{\mathbf{c}}$ Department of Studies in Chemistry, Kuvempu University, Janna Sahyadri, Shankaragatta-577451, Shimoga District, Karnataka, India venurashmi30@gmail.com

Received 8 December 2012 / Accepted 12 January 2013

\begin{abstract}
Metallophthalocyanine $(\mathrm{M}=\mathrm{Cu}, \mathrm{Co}, \mathrm{Ni}$ and $\mathrm{Zn}$ ) carrying eight (3-bromophenyl) methanimine groups at peripheral positions were synthesized by an efficient, simple and novel method. The precursor octaamino metal(II) phthalocyanines were synthesized by the reduction of the corresponding nitro metal phthalocyanines. The dark green octa-1-(3- bromophenyl)methanimine phthalocyanine derivatives were characterized by elemental analysis, magnetic susceptibility, electronic, IR and powder x-ray diffraction studies to check the purity, structural integrity and crystalline properties of the complexes. Magnetic susceptibility studies on $\mathrm{Co}$ (II) and $\mathrm{Cu}(\mathrm{II})$ octa-1-(3-bromophenyl) methanimine phthalocyanine complexes exhibit a variation of the magnetic moments as a function of field strength indicating the presence of inter molecular co-operative effect.
\end{abstract}

Keywords: Phthalocyanines, Synthesis, Octa-1-(3-bromophenyl)methanimine, Electronic, Magnetic, XRD, Thermal studies

\section{Introduction}

Phthalocyanines are man's analogues of nature's pigments of life, the porphyrins, such as chlorophyll and hemoglobin. Phthalocyanines have been the subject of much research for over 50 years $^{1}$ and many patents have been recorded ${ }^{2}$. The earlier interest in metal phthalocyanines was mainly because of their importance as dyes and pigments sh $^{3}$ Phalocyanines are well known commercial blue green pigments. The colour is due to intense absorption in the visible region of the spectrum, the $Q$-band ${ }^{4-5}$. Currently intensive research work is aiming at the production of useful phthalocyanines as sensitizers in PDT, catalysts in fuel cells ${ }^{6}$, sensors, 
display devices, information storage systems, semiconductors ${ }^{7}$ and toners in colour photocopiers and laser printers and hexadeca flurocopper phthalocyanines as the leading electron transport materials for organic semiconductors ${ }^{8-9}$.

In the present paper an attempt has been made to have a suitable subsitutent at the periphery of the molecule. The imine group was introduced by the reaction of amino derivatives of the phthalocyanine with substituted aldehydes. Even though, the literature survey revealed about the reports on synthesis and structural investigation of metal(II) $1,3,8,10,15,17,22,24$-octaamino phthalocyanines, no documentary evidences were available on synthesis and structural studies on metal(II) 1, 3, 8, 10, 15, 17, 22, 24-octa-1-(3bromophenyl) methanimine phthalocyanine complexes.

The procedure available in the literature is suitably modified and the synthetic route adopted for the synthesis of octa-1-(3-bromophenyl)methanimine substituted metal(II) phthalocyanines is given in the Scheme 1 .<smiles>O=C(O)c1cc([N+](=O)[O-])cc([N+](=O)[O-])c1C(=O)O[Na]</smiles>

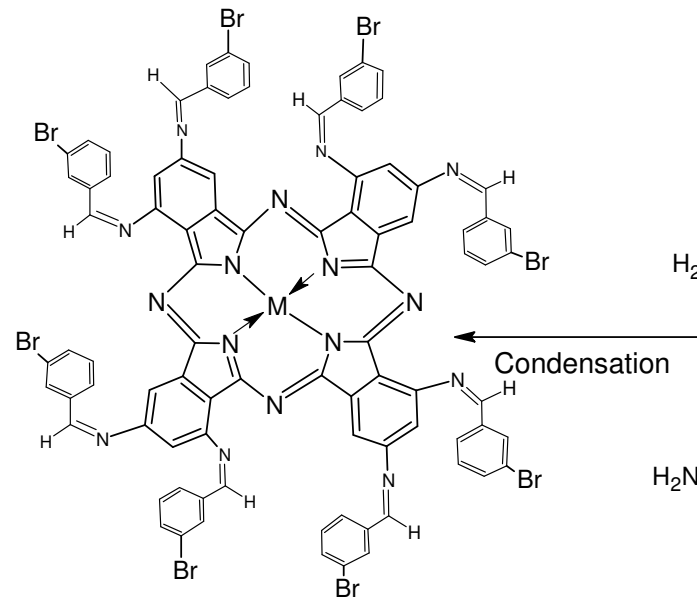

d<smiles>CC(=O)OC(C)C</smiles>

C

Scheme 1. Synthesis of metal(II) 1, 3, 8, 10, 15, 17, 22,24- octa-1-(3-bromophenyl) methanimine phthalocyanine.a. 3, 5-dinitrophthalic acid, b. M-PcON, c. M-PcOA and d. M-BrPhImPcO

\section{Experimental}

3,5-Dinitrophthalic acid was prepared as reported ${ }^{10}$; all other chemicals were of analytical grade. The metal(II)-1,3,8,10,15,17,22,24-octanitrophthalocyanines were prepared by the reported procedure ${ }^{11}$. These complexes were converted into their respective amino derivatives 
using sodium sulphide nanohydrate $\left[\mathrm{Na}_{2} \mathrm{~S} .9 \mathrm{H}_{2} \mathrm{O}\right]$ as reducing agent using the published procedure $^{12}$, quantitatively. The substituted amino complexes were converted to the imino derivatives by condensation ${ }^{13}$.

Preparation of cobalt(II) 1, 3, 8, 10, 15, 17, 22, 24-octa-1-(3-bromophenyl)methanimine phthalocyanine complex

The procedure adopted for the synthesis of cobalt(II), 1, 3, 8, 10, 15, 17, 22, 24- octanitrophthalocyanine complex is reported elsewhere ${ }^{11}$. The nitro derivative of the aforesaid complex is converted into amino derivative quantitatively by reduction using sodium sulphide nonahydrate $\left(\mathrm{Na}_{2} \mathrm{~S} 9 \mathrm{H}_{2} \mathrm{O}\right)$ in aqueous medium ${ }^{12}$. The finely grounded metal(II) 1 , $3,8,10,15,17,22,24$-octaaminophthalocyanine $(6.30 \mathrm{~g}, / 0.1$ mole $)$ was dissolved in stiochiometric quantity of $15 \mathrm{M}$ sulphuric acid, to this (19.8 g, / 0.01 mole) 3-bromobenzaldehyde was dissolved in ethyl alcohol and catalytic amount of concentrated sulphuric acid was added, and the contents were refluxed with stirring for about $5 \mathrm{~h}^{13}$.

The settled green colored condensed octa-1-(3-bromophenyl)methanimine phthalocyanine complex was washed with alcohol several times until it is free from aldehyde. Finally it was washed with distilled water and dried over anhydrous phosphorous pentaoxide in vacuum descicator.

The pigment form of the above complex was obtained by the acid pasting process, in which 1 part of the powdered sample was dissolved in 6-10 parts of concentrated sulphuric acid. The mixture was allowed to stand for 1-2 hour and then poured on to 45-50 parts of crushed ice and stirred thoroughly. The pigment thus obtained was filtered off and washed with hot water. Finally it was washed with distilled water and dried in vacuum over phosphorous pentaoxide.

Metal(II) 1, 3, 8, 10, 15, 17, 22, 24- octa-1-(3-bromophenyl)methanimine phthalocyanines of copper(II), nickel(II) and zinc(II) were prepared by the above procedure using respective amino metal phthalocyanines.

\section{Results and Discussion}

$\mathrm{C}, \mathrm{H}$ and $\mathrm{N}$ analysis were performed at Cochin University, Sophisticated Test \& Instrumentation Center, Kochi, Kerala, India. The metal content was determined by incinerating them to the oxides. Magnetic susceptibility studies were carried out at room temperature $\left(301{ }^{0} \mathrm{~K}\right)$ using a Gouy balance consisting of NP-53 type electromagnets with a DC power supply unit and a semi microbalance. Pascal's constants were used to calculate the diamagnetic corrections ${ }^{14}$ A mercury tetra thiocyanato cobalt(II) $\left(\mathrm{Hg}\left[\mathrm{Co}(\mathrm{SCN})_{4}\right]\right)$ complex was used as a calibrant and doubly distilled water used in the experiments. Shimadzu UVVisible recording spectrophotometer, UV-160A with $1 \mathrm{~cm}$ width cells was used for electronic absorption spectral studies. IR spectra were recorded using Nicolet MX-FT IR spectrometer with $\mathrm{KBr}$ pellets in the range $4000-500 \mathrm{~cm}^{-1}$ Phillip Analytical PW1710 x-ray diffractrometer is used to study the diffraction pattern. The spectra were recorded using $\mathrm{Cu} \mathrm{K} \alpha$ at the voltage of $40 \mathrm{KV}$, a current of $20 \mathrm{~mA}$, a time constant of 4 , a channel width of $7 \mathrm{~mm}$ and chart speed of $10 \mathrm{~mm} / \mathrm{min}$. Perkin-Elmer Thermal analyzer was used for simultaneous record of TGA and DTA at the rate of $10{ }^{\circ} \mathrm{C} / \mathrm{min}$ both in air, and nitrogen atmosphere.

The procedure used for the synthesis of $M$-BrPhImPcO's results in pure complexes and have dark green color for $\mathrm{Cu}(\mathrm{II}), \mathrm{Co}(\mathrm{II})$ and $\mathrm{Ni}(\mathrm{II})$ and green with brown ting for $\mathrm{Zn}(\mathrm{II})$. The metal phthalocyanine complexes, which are thermally stable and resistance towards concentrated sulfuric acid was attributed to the atomic radii of the metal in the close range of $1.35 \AA$. 
These complexes give clear solution in DMSO and DMF, but insoluble in water and most of the organic solvents, like alcohol, ether, carbon tetrachloride and benzene. The results of elemental analysis for carbon, hydrogen nitrogen and metal are in good agreement with the calculated and are summarized in Table 1 . The above results are consistent with the suggested structure in Figure 1.

Table 1. Elemental analysis and magnetic susceptibility data of metal(II)-octa-1-(3bromophenyl)methanimine phthalocyanines

\begin{tabular}{|c|c|c|c|c|c|}
\hline 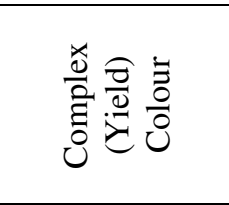 & 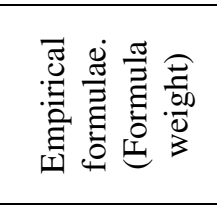 & 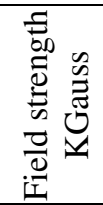 & 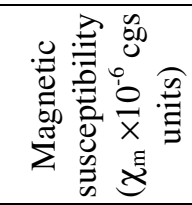 & 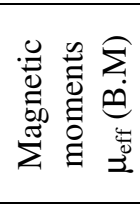 & 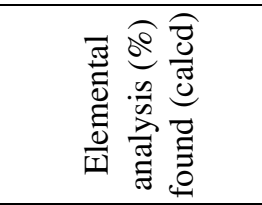 \\
\hline \multirow{2}{*}{$\begin{array}{l}\text { CoBrPhImPcO } \\
(85 \%)\end{array}$} & & 2.20 & +2577.09 & 2.92 & C; 52.96; (52.99) \\
\hline & $\mathrm{C}_{88} \mathrm{H}_{48} \mathrm{Br}$ & 2.66 & +2204.79 & 2.72 & $\mathrm{H} ; 2.35 ;(2.35)$ \\
\hline \multirow[t]{3}{*}{ Dark green } & ${ }_{8} \mathrm{~N}_{16} \mathrm{Co}$ & 3.10 & +2115.05 & 2.51 & $\mathrm{~N} ; 11.01 ;(11.01)$ \\
\hline & (1914.9) & 3.58 & +1546.46 & 1.98 & $\mathrm{Br} ; 31.50 ;(31.50)$ \\
\hline & & 4.01 & +1471.49 & 1.94 & Co; 3.11; (3.11) \\
\hline \multirow{2}{*}{$\begin{array}{l}\mathrm{CuBrPhImPcO} \\
(85 \%)\end{array}$} & & 2.20 & +2387.91 & 2.46 & C; 51.97; (51.99) \\
\hline & & 2.66 & +2093.09 & 2.27 & $\mathrm{H} ; 2.34 ;(2.36)$ \\
\hline \multirow[t]{3}{*}{ Dark green } & $\mathrm{C}_{88} \mathrm{H}_{48} \mathrm{Br}$ & 3.10 & +1673.44 & 2.01 & $\mathrm{~N} ; 11.01 ;(11.03)$ \\
\hline & ${ }_{8} \mathrm{~N}_{16} \mathrm{Cu}$ & 3.58 & +1605.75 & 1.97 & $\mathrm{Br} ; 31.49 ;(31.50)$ \\
\hline & (1919.5) & 4.01 & +1514.01 & 1.94 & $\mathrm{Cu} ; 3.11 ;(3.12)$ \\
\hline \multirow{2}{*}{$\begin{array}{l}\mathrm{NiBrPhImPcO} \\
(80 \%)\end{array}$} & & & & & $\mathrm{C} ; 52.10 ;(52.12)$ \\
\hline & $\mathrm{C}_{88} \mathrm{H}_{48} \mathrm{Br}_{8} \mathrm{~N}_{16}$ & 2.66 & -720.56 & --- & $\mathrm{H} ; 2.35 ;(2.37)$ \\
\hline \multirow[t]{3}{*}{ Dark Green } & & & & & N; 11.03; (11.05) \\
\hline & (1914.7) & & & & $\mathrm{Br} ; 31.57 ;(31.57)$ \\
\hline & & & & & Ni; 2.87; (2.89) \\
\hline \multirow{2}{*}{$\begin{array}{c}\mathrm{ZnBrPhImPcO} \\
(74 \%)\end{array}$} & & & & & C; 51.13; (51.15) \\
\hline & $\mathrm{C}_{88} \mathrm{H}_{48} \mathrm{Br}$ & 2.66 & -1145.65 & --- & $\mathrm{H} ; 2.35 ;(2.36)$ \\
\hline \multirow{3}{*}{$\begin{array}{l}\text { Green with } \\
\text { brown ting }\end{array}$} & ${ }_{8} \mathrm{~N}_{16} \mathrm{Zn}$ & & & & $\mathrm{N} ; 11.00 ;(11.02)$ \\
\hline & (1921.4) & & & & Br; 32.26; (32.26) \\
\hline & & & & & Zn; 3.21; (3.21) \\
\hline
\end{tabular}

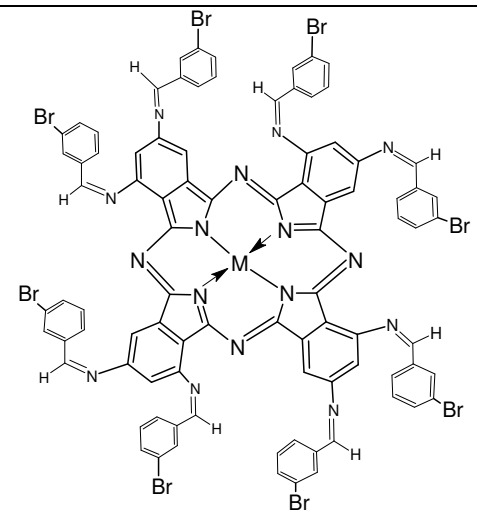

Figure 1. Suggested structure of symmetrically substituted octa-1-(3-bromophenyl)methanimine phthalocyanines, where $\mathrm{M}=\mathrm{Co}, \mathrm{Cu}, \mathrm{Ni}$ and $\mathrm{Zn}$ 


\section{Electronic spectra}

The electronic spectra of 1, 3, 8, 10, 15, 17, 22, 24-octa1-(3-bromophenyl)methanimine metal phthalocyanines were recorded in the range of $1.0-1.5 \times 10^{-4}$ in $1: 1$ sulfuric acid and the results are tabulated in Table 1. For all the complexes, a peak in the range of $609-638 \mathrm{~nm}^{15}$ was observed and assigned to Q-band, attributed to $\mathrm{a}_{1 \mathrm{u}} \rightarrow \mathrm{e}_{\mathrm{g}}$ transition. Peaks appeared in the range 236-239 $\mathrm{nm}^{16}$ are attributed to C-band. The M-BrPhImPcO's showed a peak in the range of 344-370 $\mathrm{nm}$ is assigned to B-band and is attributed to $\mathrm{a}_{2 \mathrm{u}} \rightarrow \mathrm{e}_{\mathrm{g}}$. The peaks in the longer wavelength region 730-746 $\mathrm{nm}$. A weak $L$-band was observed in the range of 205-217. For all the complexes showed a bathochromic shift with increasing intensity with respect to the corresponding parent phthalocyanines ${ }^{17}$. This is due to the presence of auxochrome $-\mathrm{Br}$ groups on the periphery of benzene portion of the complex.

\section{IR spectra}

The infrared spectra were recorded using $\mathrm{KBr}$ pellets and the results are presented in Table 2 and their spectra are given in Figure 2. A broad absorption band at $3386-3386 \mathrm{~cm}^{-1}$ was observed for all the complexes and was assigned to the hydrogen bonding formed between the nitrogen atom of the phthalocyanine molecule and hydrogen atom of the moisture absorbed on $\mathrm{KBr}$ pellets during pelletization ${ }^{18}$. A very weak signal observed in the range $2315-2330 \mathrm{~cm}^{-1}$ is due to $\mathrm{C}-\mathrm{H}$ stretching vibration on the periphery of the phthalocyanine moiety. The sharp peak at $1612-1620 \mathrm{~cm}^{-1}$ is assigned to $\mathrm{C}=\mathrm{N}$ of imine group and the peaks in the $1388-1409 \mathrm{~cm}^{-1}$ is due to $\mathrm{C}-\mathrm{N}$ aromatic stretching frequency. The absorption bands appeared around 560 $652 \mathrm{~cm}^{-1}$ were assigned to $\mathrm{C}-\mathrm{Br}$ stretching frequency of the peripheral substitution on the ring. All other remaining peaks appeared around 1052-1095 $\mathrm{cm}^{-1}, 1341-1352 \mathrm{~cm}^{-1}$ are attributed to the various skeletal vibrations of phthalocyanine ring ${ }^{19}$.

Table 2. Electronic, IR and powder XRD data of metal(II)-octa-1-(3-bromophenyl)methanimine phthalocyanines

\begin{tabular}{|c|c|c|c|c|}
\hline Complex & $\begin{array}{c}\text { UV-visible } \\
\text { absorption } \\
\lambda \text { nm (log } \in)\end{array}$ & $\begin{array}{l}\text { IR-Spectral } \\
\mathrm{cm}^{-1}\end{array}$ & $\begin{array}{l}\text { Powder. XRD data } \\
2 \theta \text { angle (d } \AA \text { ) }\end{array}$ & $\begin{array}{l}\text { Relative } \\
\text { Intensity, \% }\end{array}$ \\
\hline Co-BrPhImPcO & $\begin{array}{l}217(5.58) \\
239(5.59) \\
370(5.51) \\
617(5.03) \\
744(5.18)\end{array}$ & $\begin{array}{c}643,1052,1347 \\
1407,1616,1714 \\
2355,3395 .\end{array}$ & $\begin{array}{l}28.67(2.28) \\
44.53(2.76) \\
41.25(3.06) \\
37.68(3.85)\end{array}$ & $\begin{array}{l}100.00 \\
76.04 \\
52.19 \\
33.74\end{array}$ \\
\hline $\mathrm{Cu}-\mathrm{BrPhImPcO}$ & $\begin{array}{l}216(5.59) \\
236(5.60) \\
344(5.41) \\
638(4.82) \\
746(4.97)\end{array}$ & $\begin{array}{c}652,1088,1347 \\
1533,1620,1714 \\
2357,3390 .\end{array}$ & $\begin{array}{l}26.13(2.36) \\
23.58(2.48) \\
44.38(2.76) \\
36.89(3.12)\end{array}$ & $\begin{array}{l}100.00 \\
71.58 \\
53.44 \\
31.27\end{array}$ \\
\hline $\mathrm{Ni}-\mathrm{BrPhImPcO}$ & $\begin{array}{l}214(5.58) \\
238(5.59) \\
365(5.46) \\
609(4.89) \\
730(4.95)\end{array}$ & $\begin{array}{c}\text { 643. } 1093,1341 \\
1548,1612,1719 \\
2349,3405 .\end{array}$ & $\begin{array}{l}27.75(2.20) \\
22.29(2.86) \\
42.18(3.01) \\
38.64(3.21)\end{array}$ & $\begin{array}{l}100.00 \\
76.45 \\
50.35 \\
31.64\end{array}$ \\
\hline Zn-BrPhImPcO & $\begin{array}{l}205(5.58) \\
239(5.59) \\
368(5.57) \\
619(5.41) \\
759(5.32)\end{array}$ & $\begin{array}{c}560,1095,1352 \\
1409,1616,1714 \\
2350,3410 .\end{array}$ & $\begin{array}{l}30.45(2.29) \\
24.95(2.84) \\
41.38(3.34) \\
39.98(3.54)\end{array}$ & $\begin{array}{l}100.00 \\
74.65 \\
49.39 \\
34.90\end{array}$ \\
\hline
\end{tabular}




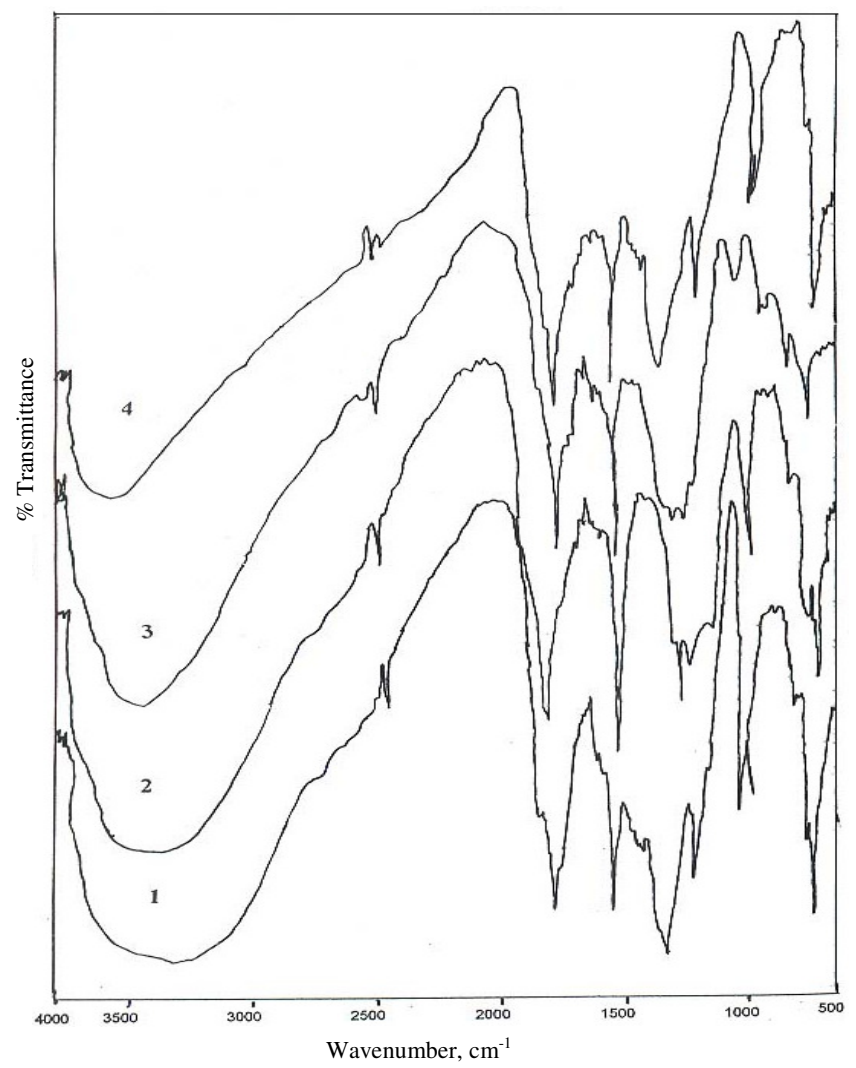

Figure 2. IR absorption spectra of (1) Cu-BrPhImPcO (2) Co-BrPhImPcO (3) Ni-BrPhImPcO (4) $\mathrm{Zn}-\mathrm{BrPhImPcO}$

\section{Magnetic susceptibility}

The magnetic susceptibility measurements for 1, 3, 8, 10, 15, 17, 22, 24-octa-1-(3bromophenyl)methanimine phthalocyanines of copper, cobalt, are consistent with paramagnetic nature and nickel, zinc an diamagnetic nature. A summary of the magnetic properties over the range of applied magnetic field strength 2.20-4.45 KGauss are reported in Table 1. The values reported in the table are the average of the three independent determinations. Magnetic susceptibility measurements on $\mathrm{Cu}-\mathrm{BrPhImPcO}$ and $\mathrm{Co}-\mathrm{BrPhImPcO}$ are in agreement with paramagnetic nature of the complexes and that of $\mathrm{Ni}-\mathrm{BrPhImPcO}$ and $\mathrm{Zn}-\mathrm{BrPhImPcO}$ are diamagnetic. The observed magnetic moment values for $\mathrm{Cu}-\mathrm{BrPhImPcO}$ and $\mathrm{Co}-\mathrm{BrPhImPcO}$ are higher than expected for $\mathrm{S}=1 / 2$ spin state but less than their corresponding unsubstituted counterparts. Also, the $\mu_{\text {eff }}$ values of the complexes are found to vary with the strength of the applied magnetic field and this is due to intermolecular cooperative effect ${ }^{20}$.

The orbital contributions is found to be higher at lower magnetic field than that of higher one evidenced by higher $\mu_{\text {eff }}$ values at lower field strength and it may be accounted for the contribution of magnetic anisotropy of the strong phthalocyanines $\pi$ electronic current as reported in the literature ${ }^{21}$. 
The observed higher values of magnetic moment, at lower magnetic field strength may be due to the intermolecular magnetic interaction coupled with strong $\pi$-electron current of phthalocyanine molecule. Crystallographic studies ${ }^{22}$ on phthalocyanines revealed that, during the process of stacking, each phthalocyanine molecule is stacked to the neighbouring molecule along the $b$-axis contribute either a -N-atom at a distance of $3.38 \AA$ one above and one below about the central metal atom as shown in Figure 3(a) or may be placed one above the other with the separation of two molecules by a distance of $3.38 \AA$ as represented in Figure 3(b). This minimum interplanar distance seems to provide a suitable pathway for spin-spin coupling interaction between adjacent metal atoms either directly or super exchange through the $\mathrm{N}$ atoms of the molecule. The extent of super exchange interaction between the molecules depends primarily on angle of inclination of the plane of the molecules, type of the metal atom, nature of the substitutent and metal-metal distance. It seems, the exchange interaction coupled with orbital contribution is the cause for the observed higher magnetic moments for $\mathrm{Cu}-\mathrm{BrPhImPcO}$ and $\mathrm{Co}-\mathrm{BrPhImPcO}$ at the lower magnetic field strength. But at higher magnetic fields, it seems molecules suffer tumbling, resulting in decrease in intermolecular distance which in turn favour an effective intermolecular interaction.

The crystallographic studies revealed that the metal phthalocyanines of $\mathrm{Cu}, \mathrm{Co}, \mathrm{Ni}$ and $\mathrm{Zn}$ has square planar structure with $\mathrm{D}_{4 \mathrm{~h}}$ symmetry and are isomerphous ${ }^{19}$. The molecular plane is approximately normal to a-b plane and molecules are stacked along the short b-axis. The molecular planes are inclined to the a-c axis at an angle of $45^{\circ}$. Thus the complexes stacked in column with $N$-atoms above and below on every metal atom (Figure 3 ) and hence the nearest neighbouring molecule along the $b$-axis contributes ${ }^{16} \mathrm{~N}$-atom at the interplanar distance $3.4 \AA$.

\section{Powder XRD}

The x-ray diffraction spectra of M-BrPhImPcO's are taken through a range of $2 \theta$ angles $6-70^{\circ}$ showed are not identical peaks (Table 2). Two peaks were observed with one sharp at lower angle with maximum intensity and the other at higher angle with higher intensity. The inter planar spacings on these angle gave the following values. Co-BrPhImPcO 3.85, 37.68 $\AA$; Cu-BrPhImPcO 3.12, $36.89 \AA$ Aं; Ni-BrPhImPcO 3.21, $38.64 \AA$ and Zn-BrPhImPcO 3.54, $38.98 \AA$ clearly indicating the crystanilline nature of the complex. The observed patterns are very much similar to unsubstituted parent phthalocyanines except the broadening of the peaks in the case of title complexes with diffused intensity. The broadening may be due to the presence of substituents and which seems to play an important role in the stacking of the metal phthalocyanine derivatives. X-ray diffraction patterns are used only to explain crystallinity qualitatively.

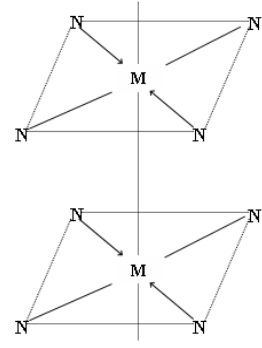

$\mathrm{a}$

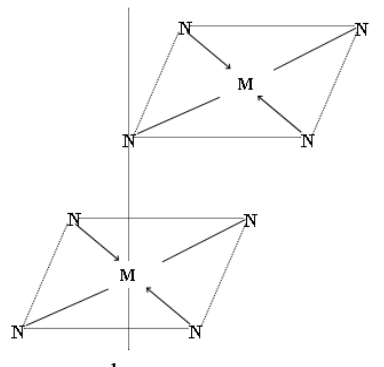

b

Figure 3. Probable molecular stacking of metal phthalocyanines $\mathrm{M}=\mathrm{Cu}, \mathrm{Co}, \mathrm{Ni}$ and $\mathrm{Zn}$, $\mathrm{N}=$ central nitrogen atoms of the phthalocyanine structure 


\section{Thermogravimetric and kinetic studies}

Thermogravimatric analytical data of octa-1-(3-bromophenyl)methanimine phthalocyanine complexes both in air and nitrogen atmosphere are summarized in the Table $3 \& 4$. It is observed that the decomposition of the above complexes occurs generally in two steps, revealed that the initial weight loss of $2-3 \%$ corresponding to moisture. The first step degradation in air, which takes place in the temperature range of $250-350{ }^{\circ} \mathrm{C}$, may be accounted for the loss of eight substituted imine groups.

Table 3. Kinetics and Thermodynamic parameters of metal(II)-octa-1-(3-bromophenyl)methanimine phthalocyanines in air and nitrogen atmosphere

\begin{tabular}{|c|c|c|c|c|c|c|}
\hline \multicolumn{2}{|l|}{ Compounds } & $\begin{array}{c}\text { Activation } \\
\text { energy Eo } \\
\mathrm{kJ} / \mathrm{mole}\end{array}$ & $\begin{array}{l}\text { Frequency } \\
\text { Factor } \\
\ln \mathrm{A} \text { min }^{-1}\end{array}$ & $\begin{array}{c}\Delta \mathrm{H} \\
\mathrm{kJ} / \mathrm{mole}\end{array}$ & $\begin{array}{l}\Delta \mathrm{S} \\
\mathrm{J} / \mathrm{K}\end{array}$ & $\underset{\mathrm{kJ} / \mathrm{mole}}{\Delta \mathrm{G}}$ \\
\hline \multirow{3}{*}{$\begin{array}{c}\mathrm{Cu}-\mathrm{BrPhImPcO} \\
\text { II }\end{array}$} & \multirow{3}{*}{ I } & 5.87 & 6.18 & 2.74 & -165.06 & 62.40 \\
\hline & & $(0.73)$ & $(2.01)$ & $(-1.29)$ & $(-160.01)$ & (61.54) \\
\hline & & 3.74 & 5.38 & -0.75 & -152.27 & 81.65 \\
\hline \multirow{5}{*}{$\begin{array}{c}\mathrm{Co}-\mathrm{BrPhImPcO} \\
\text { II }\end{array}$} & \multirow{5}{*}{ I } & (1.51) & $(5.48)$ & $(-2.41)$ & $(-149.78)$ & (79.54) \\
\hline & & 0.89 & 6.39 & -1.38 & -176.08 & 74.95 \\
\hline & & (0.69) & (3.38) & $(-1.10)$ & -174.10 & (74.78) \\
\hline & & 4.65 & 7.41 & 2.87 & -143.94 & 79.54 \\
\hline & & (1.24) & (4.68) & $(-1.31)$ & $(-141.99)$ & (77.21) \\
\hline \multirow{4}{*}{$\underset{\text { II }}{\mathrm{Ni}-\mathrm{BrPhImPcO}}$} & \multirow{3}{*}{ I } & 1.45 & 5.21 & -1.22 & -159.67 & 72.84 \\
\hline & & $(0.70)$ & $(2.24)$ & $(-.0 .76)$ & $(-157.58)$ & (70.58) \\
\hline & & 5.87 & 4.45 & -0.83 & -149.79 & 81.76 \\
\hline & \multirow{5}{*}{ I } & $(1.54)$ & $(3.81)$ & $(-0.82)$ & $(-143.63)$ & (84.21) \\
\hline \multirow{4}{*}{$\begin{array}{c}\mathrm{Zn}-\mathrm{BrPhImPcO} \\
\text { II }\end{array}$} & & 1.95 & 3.48 & -0.95 & -175.97 & 75.24 \\
\hline & & $(0.68)$ & (2.39) & $(-1.49)$ & $(-173.37)$ & (74.98) \\
\hline & & 8.54 & 7.98 & 2.84 & -142.72 & 82.49 \\
\hline & & $(5.54)$ & $(6.44)$ & $(-1.51)$ & $(-140.44)$ & $(80.93)$ \\
\hline
\end{tabular}

(I and II corresponds to the I and II stage of degradation and the values in the parenthesis are for nitrogen atmosphere)

Table 4. TGA data of metal(II) -octa-1-(3-bromophenyl)methanimine phthalocyanines

\begin{tabular}{|c|c|c|c|c|c|}
\hline \multirow[b]{2}{*}{ Compound } & \multirow{2}{*}{$\begin{array}{l}\text { Temperature of } \\
\text { decomposition, } \\
{ }^{\circ} \mathrm{C}\end{array}$} & \multicolumn{2}{|c|}{ Mass Loss } & \multirow{2}{*}{$\begin{array}{c}\text { Probable } \\
\text { fragment } \\
\text { loss }\end{array}$} & \multirow[b]{2}{*}{$\begin{array}{l}\text { Nature of } \\
\text { DTA peak }\end{array}$} \\
\hline & & $\begin{array}{c}\%, \\
\text { Found }\end{array}$ & $\begin{array}{c}\%, \\
\text { Calcd }\end{array}$ & & \\
\hline \multirow[t]{2}{*}{$\mathrm{Cu}-\mathrm{BrPhImPcO}$} & $250-350$ & 37.34 & 36.40 & $8 \mathrm{Br}$-groups & Exothermic \\
\hline & $350-540$ & 62.67 & 62.01 & $+\mathrm{Pc}$ moiety & \\
\hline \multirow[t]{2}{*}{ Co-BrPhImPcO } & $250-350$ & 37.58 & 36.40 & $8 \mathrm{Br}$-groups & Exothermic \\
\hline & $350-540$ & 62.51 & 62.08 & + Pc moiety & \\
\hline \multirow[t]{2}{*}{ Ni-Br PhImPcO } & $250-350$ & 36.89. & 37.02 & $8 \mathrm{Br}$-groups & Exothermic \\
\hline & $350-540$ & 62.21 & 65.01 & + Pc moiety & \\
\hline \multirow[t]{2}{*}{ Zn-Br PhImPcO } & $250-350$ & 36.78 & 37.49 & 8 Br-groups & Exothermic \\
\hline & $350-540$ & 62.37 & 62.45 & + Pc moiety & \\
\hline
\end{tabular}

The major weight loss was observed for all the complexes in the second step in the temperature ranges of $350-600{ }^{\circ} \mathrm{C}$ corresponds to the oxidative degradation of remaining phthalocyanine moiety. Analysis of the final charred residue corresponds to the corresponding metal oxides ${ }^{23}$. The thermal decomposition of bromo substituted metal phthalocyanine 
complexes in the nitrogen atmosphere appears to be very slow. For $\mathrm{Co}-\mathrm{BrPhImPcO}, 62 \%$ of the complex was found to be decomposed at $700{ }^{\circ} \mathrm{C}$. For $\mathrm{Cu}-\mathrm{BrPhImPcO}, \mathrm{Ni}-\mathrm{BrPhImPcO}$ about $55 \%, 52 \%$ and $41 \%$ loss of the mass was observed for $\mathrm{Zn}-\mathrm{BrPhImPcO}$. Above trend confirms the relative stability of these complexes in the order $\mathrm{Co}-\mathrm{BrPhImPcO}>\mathrm{Cu}-\mathrm{BrPhImPcO}>\mathrm{Ni}$ $\mathrm{BrPhImPcO}>\mathrm{Zn}-\mathrm{BrPhImPcO}$. DTA results revealed that all degradation steps are exothermic in nature. Kinetic and thermodynamic parameters of the title complexes have been evaluated by Boride's method ${ }^{24}$ for the two stages of decomposition.

The activation energies, $\left(\mathrm{E}_{0}\right)$ for the loss of periphery 3-bromo substitutent compound lies in the range of 0.89 to $5.87 \mathrm{~kJ} / \mathrm{mole}$. It may be expected that as soon as the periphery substitutents are expelled, the rupture of the main phthalocyanines ring takes place. Exothermic behavior of the degradation clearly indicated by their negative entropies. The changes in entropies $\Delta \mathrm{S}$ are negative for little complexes and varies from -159.67 to $-176.08 \mathrm{~kJ}$. It is clear from the values of entropies for the decomposition that the removal of functional groups are associated with more negative entropies.

\section{Conclusion}

A simple and convenient method has been optimized for the synthesis of pigments $1,3,8$, 10, 15, 17, 22, 24-octa-1-(3-bromophenyl)methanimine phthalocyanines of $\mathrm{Cu}$ (II), $\mathrm{Co}$ (II), $\mathrm{Ni}(\mathrm{II})$ and $\mathrm{Zn}$ (II). Magnetic susceptibility studies revealed the paramagnetic behavior of $\mathrm{Cu}$ (II) and $\mathrm{Co}$ (II) octa-1-(3-bromophenyl)methanimine phthalocyanine derivatives and the variation of magnetic moments with magnetic field indicated the presence of intermolecular co-operative effect. Thermogravimatric analysis of the complexes in an inert atmosphere revealed the stability in the order $\mathrm{Cu}-\mathrm{BrPhImPcO}>\mathrm{Co}-\mathrm{BrPhImPcO}>\mathrm{Ni}-\mathrm{BrPhImPcO}>$ $\mathrm{Zn}$-BrPhImPcO.

\section{Acknowledgment}

The authors are thankful to the Chairman, Department of Industrial Chemistry and Principal, Sahyadri Science College, Kuvempu University for providing the basic laboratory facilities.

\section{References}

1. Linstead, British Association for the Advancement of Science Report; 1933. p. 465.

2. Moser F H and Thomas A L, The phthalocyanine compounds, Boca Raton, FL: CRC Press, Inc.; 1983.

3. Dandridge A E, Drescher H A and Thomas J, (To Scottish Dyes Ltd) British Patent, 1929, 169, 822.

4. Drechsler V, Hanack M. Atwood J L, Daries J E D, Macnicol D D and Vogtle F, Eds., Pergamon, In Comprehensive Supra molecular Chemistry, New York 1996, 9, 283.

5. Snow A W and Barger W R, Phthalocyanine properties and applications, Lenzoff C C and Lever A B P, VCH Publications, New York 1989, 1, 343.

6. Gregory P, J Porphyrins Phthalocyanines, 2000, 3(4), 432.

7. Venkataraman K, The Chemistry of Synthetic Dyes, Academic Press, New York $1952,02$.

8. Leznoff C C and Lever A B P, Phthalocyanines Properties and Applications, Vol. 1. New York: VCH Publishers Inc. 1989.

9. Vartanyam A T, Zh. Fig Khim, 1948, 22, 769 and Eley, Nature (London) 1948, 162, 819 and Applications Vol. 1. New York: VCH Publishers Inc. 1989.

10. Fasiulla, Moinuddin Khan M H, Harish M N K, Keshavayya J and Venugopala Reddy K R, Dyes \& Pigments, 2008, 76, 557-563. 
11. Venugopala Reddy K R and Keshavayya J, Turk J Chem., 2002, 26(4), 573.

12. Venugopala Reddy K R and Keshavayya J, Synth React Inorg Met-Org Chem., 2002; 32(7), 1235-1244.

13. Vogel's textbook of practical organic chemistry, V Ed., UK, Longman Group UK Ltd, 1989.

14. Wright J D, Prog Surf Sci., 1989, 31, 01.

15. Moinuddin Khan M H, Fasiulla, Harish M N K, Keshavayya J and Venugopala Reddy K R, J Coordination Chem., 2007, 60(12), 1255-1267.

16. Venugopala Reddy K R, Harish M N K, Fassiulla, Moinuddin Khan M H and Keshavayya J, J Fluorine Chem., 2007, 128, 1019-1025.

17. Venugopala Reddy K R and Keshavayya J, Synth React Inorg Met-Org Chem., 2002, 32(7), 1235.

18. Somashekarappa M P and Keshavayya J, J Saudi Chem Soc., 1999, 3(2), 113 -119.

19. Achar B N, Fohlen G M, Parker J A and Keshavayya J, Polyhedron, 1987, 6(6), 1463-1467.

20. Somashekarappa M P, Venugopala Reddy K R, Harish M.N.K and Keshavayya J, J Molecular Struct., 2005, 753(1-3), 190-194.

21. Somashekarappa M P and Keshavayya J, Synth React Inorg Met-Org Chem., 1999; 29(5), 767-783.

22. Achar B N and Bhandari J M, Synth React Inorg Met-Org Chem., 1993, 23(1), 133-148.

23. Vogel Arthur I, Quantitative inorganic analysis, $3^{\text {rd }}$ Ed., London: Longman Publishers; 1964.

24. Broido A, J Polym Sci., 1969, Part-2A(7), 1761. 